lections of old inhabitants and from such records as may be accessible, the most important events in the early history of such county. There are many local histories extant, from which much valuable information can be obtained. The lives of our pioneers which were marked by so many striking characteristics of heroic daring, of patient endeavor, of deprivation, of sacrifice, of danger, coupled with the burdens of increasing toil, must, to future generations, be a theme of manifold importance. The little $\log$ cabin in the wilderness, the $\log$ school-house and the $\log$ church formed the foundation of Indiana's greatness. Primitive agriculture, the crude implements, the old-time corn huskings, quiltings, wool pickings, etc., etc., are things of the past. The loom and the wheel, the home-made wares and fabrics are no more. Much regret exists that the crude implements of agriculture, the wheels and looms of the cabin homes have not been preserved. Greater regret will be felt if we fail to preserve the history of those times, which should include also all available records of courts, schools, printing presses, churches, roads, mills, mines, flat and steamboating, canals, the early railroads, the Indian tribes, their removal, the conflicts with Indians, early hunting and fishing, our great forests, saw mills-in short, everything connected with the pioneer associations of our great commonwealth.

We owe to future génerations a comprehensive history of the heroic struggle and the conditions and environments which formed the foundation of our present greatness.

Cognizant of the fact that the public press molds sentiment and moves the people in public enterprise, I earnestly solicit the co-operation of the newspapers in the forwarding of this important work. The active aid of county commissioners and other local officials is invoked to the end that the purposes herein contemplated may be consummated.

Done at the Capitol, in the City of Indianapolis, this twenty-sixth day of March, in the year of our Lord one thousand nine hundred, of the Independence of the United States the one hundred and twenty-fourth, and of the State the eighty-fourth.

UNION B. HUNT,

By the Governor:

JAMES A. MOUNT.

Secretary of State.

[INDIANA STATE SEAL]

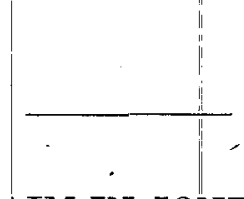

\title{
HISTORY OF A CLAIM IN JONES COUNTY IN 1838.
}

Major John Russ, a native of Maine, about 55 years of age, came to Dubuque, in May, 1838, when a man named Smith, who had been one of a surveying party, told him of 
the Buffalo fork of the Wapsipinecon as affording a fine water-privilege, and proposed that they should go and see the place. They went thither on foot. Major Russ built a cabin on the west bank of the Wapsipinecon in the thick timber. In the summer he would wade into the river at night, and with torch and gun obtain a supply of fish for food. The summer was extremely hot. Major Russ and Smith and another young man who had come to their cabin died of bilious fever, which also prostrated two other young men, one with his wife and child, who had come to the cabin. These recovered after being reduced almost to skeletons by fever and ague. They were now visited by Timothy Davis,* of Dubuque, to whom the lady said she had not seen a female face during the whole sickness of the family.

In November, a son of Major Russ came out and sold his father's interest to Gideon Ford, of Massachusetts. The claim is the most western that has thus far been made in that part of Iowa Territory. The claim and mill-privilege have since fallen into the possession of Ford and Davis, named above, and of George H. Walworth, of Alton, Ill. They have erected a saw-mill, which will prove as great an accommodation to the Territory doubtless as any other in it.

Mr. Davis was originally from Oneida county, N. Y., but for 20 years a resident of St. Mary's Landing, Mo., where by enterprise he amassed a fortune, which he has invested in Dubuque and its neighborhood, whither he removed last summer. Mr. Walworth was of the gallant little baud of heroes who periled their lives at Alton on the night of the memorable 7th of November, 1837, in defense of the liberty of the press and free discussion. Iowa may well be proud of such a citizen.

We have written this sketch from notes taken last week at Dubuque to show our eastern readers some of the perils

*Timothy Davis, mentioned in the above sketch, was Representative from Iowa in the 35th Congress, 1857-9; Geo. H. Walworth was Representative from Jones and Codar counties, in the 2d, $3 \mathrm{~d}, 5$ th, and 6th Legislative Assembly of Iowa Territory. 
attending " taking up a claim" in the Far West. We relate it as in favor of the principle of preemption rights, and to undeceive those who entertain the idea that the preemption system favors only "land-pirates and robbers." It is thus that the frontiers of our country are extended into the wilderness, and the way opened for the advance of civilization. -Peoria Register and N. W. Gazetteer. Vol. 3., No. 8., May 25, 1839. ' Samuel H. Davis, Editor.

Judge Williams, of Iowa.-This gentleman, who is distinguished for great versatility of talent, paraded with the volunteers of Bloomington, Iowa, and marched at the head playing the fife. The Judge is a perfect specimen of a happy man. $\mathrm{He}$ is a devout member of the Methodist church, and attends scrupulously to his religious duties. He is, also, one of the best temperance lecturers we ever heard; Judge of the Second District, Iowr; Associate Judge of the Supreme Court; a fine poet; a superior musician; fifer for the Texas volunteers; the tallest kind of a companion we: ever met with at the social board; and he tells the best story of any humorist of the day.-The Herald, Bloomington, Iowa, June 12, 1846.

Crops in Iowa,- Our wheat, rye and oat crops have been gathered. The yield is as large as usual, if not larger-and we need hardly add that the crops in Iowa are generally the largest in the world. The corn crop will be tremendous. "Oh, this ruined country!'-Burlington Hawk-Eye, August 8,1840 .

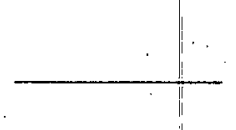

The time has passed when the things that are old can hope to be treated with respect merely because they are old. -Rev. Father Thurston, S. J. 
Copyright of Annals of Iowa is the property of State of Iowa, by \& through the State Historical Society of Iowa and its content may not be copied or emailed to multiple sites or posted to a listserv without the copyright holder's express written permission. However, users may print, download, or email articles for individual use. 